\title{
Geotourism: A Systematic Literature Review
}

\author{
Rannveig Ólafsdóttir * and Edita Tverijonaite \\ Department of Geography and Tourism Studies, Faculty of Life and Environmental Sciences, \\ University of Iceland, Askja, Sturlugata 7, 101 Reykjavík, Iceland; edt1@hi.is \\ * Correspondence: ranny@hi.is
}

Received: 8 June 2018; Accepted: 21 June 2018; Published: 26 June 2018

\begin{abstract}
Geotourism is one of the newest concepts within tourism studies today. The popularity of geotourism has likewise grown rapidly over the past few decades. This rapidly growing popularity and the growing body of research on geotourism create the need for a comprehensive review of existing literature on the subject. The present study aims to systematically review scientific literature on geotourism published over the past two decades by identifying what knowledge has been produced on geotourism in the scientific literature and by analyzing the evolving research trends in geotourism during the same time period. The results reveal that researchers are placing an increasing focus on geotourism. A geographical analysis of the study areas indicates a true global distribution, encompassing studies of 53 countries altogether. Most of the research focusses on identifying, describing, and assessing the geoheritage of the areas in question together with their geotourism potential. The volume of research on these topics is growing at a rapid pace. Other common research topics as regards geotourism include management of geotourism and geoheritage, new geosite/geomorphosite assessment models, together with other methodological approaches. The results further indicate that researchers are less interested in geotourism stakeholders such as tourists and local communities, and that only a very small number of studies examine geotourism in the context of sustainable development. The vast majority of the studies utilize empirical data as the basis of the research or for the testing of proposed models and methodology. The present review identifies a need for a larger body of empirical research focusing on (i) sustainability of geotourism, including actual impacts of geotourism on the geoheritage and on the ecosystems of geotourism areas, (ii) knowledge on effective management of the main challenges of geotourism, as well as (iii) on stakeholders and their complex interrelations, including the effects of geotourism on local communities and their well-being.
\end{abstract}

Keywords: geotourism; geoheritage; tourism management; systematic literature review

\section{Introduction}

Special geological formations have long attracted visitors worldwide. In Iceland nearly all travelogues written by foreign visitors in the eighteenth and nineteenth centuries state that the country's geological formations were the major reason for their visits. According to Hose [1], the geology-based tourism in England has its origins in the late seventeenth century. It is thus likely that it came about in the same period in other countries. As a concept, however, geotourism is relatively new [2,3]. It was first formulated just over twenty years ago by Hose [4], who defined geotourism as:

"The provision of interpretive and service facilities to enable tourists to acquire knowledge and understanding of the geology and geomorphology of a site (including its contribution to the development of the Earth sciences) beyond the level of a mere aesthetic appreciation." 
During the past two decades the concept has been redefined by various researchers in different countries, and these definitions are by no means uniform. While researchers in the United Kingdom and Australia [3-7], identify geology and landscape as central elements of geotourism, National Geographic [8] in the United States applies a broader approach, defining geotourism as "tourism that sustains or enhances the geographical character of the place being visited, including its environment, culture, aesthetics, heritage and the well-being of its residents". According to this definition, geotourism is a branch of sustainable tourism, which instead of focusing on minimizing impact on the ecological environment seeks to preserve all natural and human attributes which render a given location distinct from others. Subsequently, in collaboration with local organizations, National Geographic published Geotourism MapGuides, which present over twenty tourism destinations worldwide and seek to inform visitors concerning the more sustainable choices provided in each area, thereby helping to enhance the region's geographical character and contributing to the well-being of local people $[9,10]$. Boley and Nickerson [11] argue that these National Geographic publications significantly contributed to the popularization of geotourism as a sustainable tourism development strategy. At the same time, researchers emphasize the importance of narrowing the definition of geotourism to geology and its conservation [1-3,5,12], pointing out that applying a broader approach to geotourism might reduce the impact of the concept. Thus, according to Newsome and Dowling [3], a more specific definition of geotourism helps to develop a focused strategy, which is necessary in order to achieve the aims of geotourism, such as geodiversity conservation, visitor education, and empowering local communities by providing knowledge about their geological resources and employment opportunities. In 2010 Newsome \& Dowling proposed one of the most commonly used definitions of geotourism:

"Geotourism is a form of natural area tourism that specifically focuses on geology and landscape. It promotes tourism to geosites and the conservation of geodiversity and an understanding of earth sciences through appreciation and learning. This is achieved through independent visits to geological features, use of geo-trails and viewpoints, guided tours, geo-activities and patronage of geosite visitor centres."

Dowling [13] further notes that the 'geological' definition views geotourism as a type or form of tourism, while the 'geographical' definition views it more as an approach to tourism, similar to sustainable tourism. Dowling argues that these two perspectives are not mutually exclusive and should be combined in the concept of geotourism. This accords with the principles of geotourism elaborated by Newsome and Dowling [3] based on the principles of ecotourism: geotourism is "geologically based, environmentally educative, generating tourist satisfaction, sustainable and being locally beneficial". Dowling [13] emphasizes that knowledge concerning geology is essential for a full understanding of the geological processes taking place in a given area or a region, and for this reason geotourism employs an 'ABC' approach, meaning that the Abiotic components (geology and climate) determine the Biotic components (flora and fauna), and in combination with the latter define the Cultural elements, such as the lifestyle of people. As such it is important to gather and disseminate knowledge concerning geoheritage and its effects on other aspects of an area when developing a new geotourism destination. Definitions of geotourism appear to have moved closer to one another, emphasizing sustainability as a vital element of the concept today.

An important tool which facilitates sustainable geotourism development is use of geoparks, which are described by UNESCO [14] as "geographical areas where geological heritage sites are part of a holistic concept of protection, education, and sustainable development". Although the concept of geoparks was already current in the late 1980s, it rapidly grew in importance due to an active collaboration between the European Geoparks Network (EGN) and UNESCO, which subsequently resulted in the creation of the Global Geoparks Network (GGN) in 2004 [15-17]. Currently the GGN has 140 member geoparks from 38 countries and this number seems to be rapidly increasing [18]. Additionally, some countries have networks of national geoparks parallel to their membership of GGN [15]. Given that a necessary step for the establishment of geoparks and the development 
of geotourism is the identification of the geoheritage of each area [19], numerous geosites and geomorphosites with various levels of geoheritage value and geotourism potential have been identified worldwide. An increasing amount of research has been conducted with the aim of presenting and classifying geosites and geomorphosites and their geotourism potential.

The rapidly growing popularity of geotourism and the growing body of research on the subject creates the need for a comprehensive review of existing literature on geotourism. Ruban [20] produced a geographical review of literature on geotourism published between 2012 and 2014 which indicated that geotourism was by then being researched worldwide. However, considering the escalating growth of geotourism over the past few years, further knowledge regarding the main themes and methods trending in geotourism research and potential gaps in knowledge is urgently needed. The general aim of this paper is to systematically review scientific literature on geotourism published in the two decades since the first official definition of geotourism term was put forward in 1995, in order to identify (i) what knowledge has been produced on geotourism in the scientific literature; and (ii) what trends are evolving in geotourism research.

\section{Methods}

A systematic literature review was carried out to identify what research trends are currently evolving in geotourism studies. As pointed out by various researchers [21-23] a systematic search, selection, and categorization of studies allows for clear, reproducible results and helps limit potential bias. Moreover, Petticrew and Roberts [24] stress that a systematic literature review maps areas of uncertainty and identifies gaps in research by providing a better overview of studies which research the same topic. Such a review is therefore the approach most compatible with the aims of the present paper on the relatively new concept of geotourism, since a systematic review aims to synthesize emerging knowledge, and helps direct future research.

The review criteria are based upon three steps: (1) literature search; (2) selection of relevant studies; (3) categorization and synthesis of the findings (Figure 1). To assure the quality of the review, only papers published in peer-reviewed journals were taken into consideration. Book chapters, conference proceedings, editorials, reviews, research notes, short communications, and reports were excluded from this review. Since English is by far most commonly used language in academic research, only papers published in English were selected. The search was carried out in the three largest online databases of scientific research literature: Scopus, Web of Science, and Science Direct. The controlled vocabulary keyword used for the search was 'geotourism', since it is a broad concept comprising elements related to tourism which focus on geological elements of geosites, geoparks, and ex-situ locations $[20,25]$. Papers which include this term in the title, abstract, topic heading, or keywords were taken into consideration in the review process. The search was carried out in January and February 2018. Since the present paper aims to investigate how research trends concerning the concept of geotourism evolve over time, no time interval was selected for the systematic literature search. The literature search produced a total of 523 results, 269 in Scopus, 207 in Web of Science, and 47 in Science Direct.

In the second step any duplicates were filtered, resulting in 330 papers, whose abstracts were then screened. Additionally, a total of 79 studies that did not meet the selection criteria were removed. The full texts of the remaining 251 papers were then reviewed in-depth. A further 32 studies that were not directly related to geotourism, as well as reviews, case reports, research notes, or short communications were excluded from the review. By examining the bibliographies of the remaining papers an additional 37 related articles were identified, and after assessing the complete articles which were added to the sample of papers as a result, a total of 256 research papers were selected for the present review.

In the third step of the systematic review an Excel datasheet was produced for the purpose of further analyzing papers which included information concerning the authors, year of publishing, journal title and discipline, and geographic location of each study. The papers were also categorized 
on the basis of their aims and topics, the research methods applied, and their results. A summary and synthesis of the most important results enabled the identification of the main research trends in geotourism research and of areas which require further research.

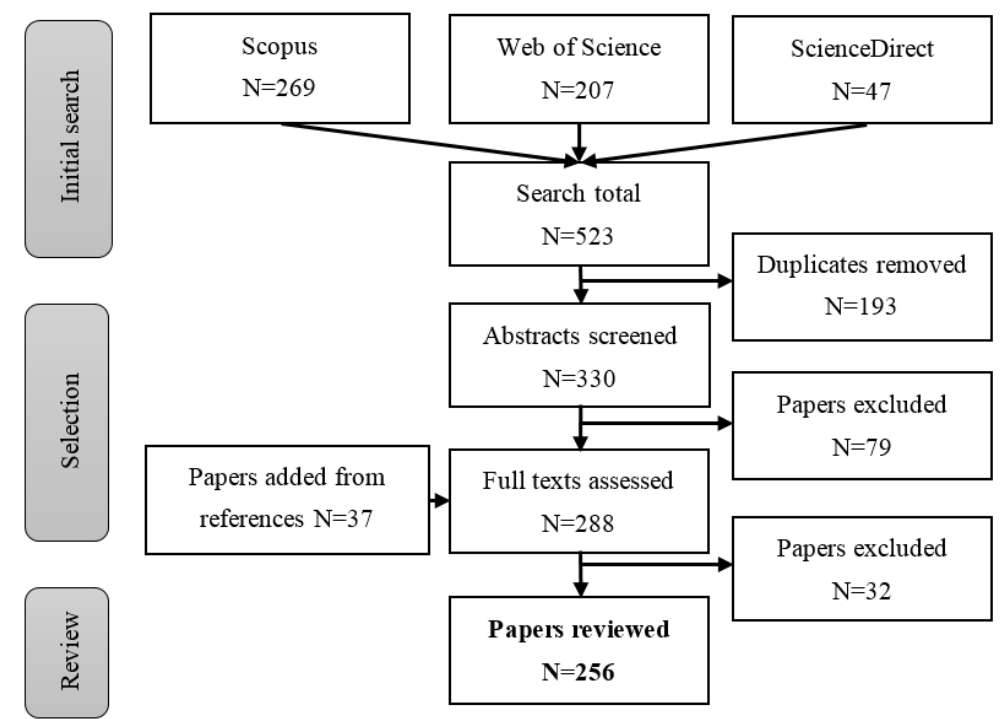

Figure 1. Flow chart illustrating the process and major steps in the literature search and selection.

\section{Results}

\subsection{Characteristics of the Scientific Literature on Geotourism}

The results reveal a growing focus of researchers on geotourism. The oldest paper included in the review was published in 2002, and during the first decade of the millennium the number of papers published in peer-reviewed journals grew at a slow pace. In the following decade, by contrast, the number of published papers grew rapidly (Figure 2). In 2017 a total of 53 papers were published on topics directly related to geotourism.

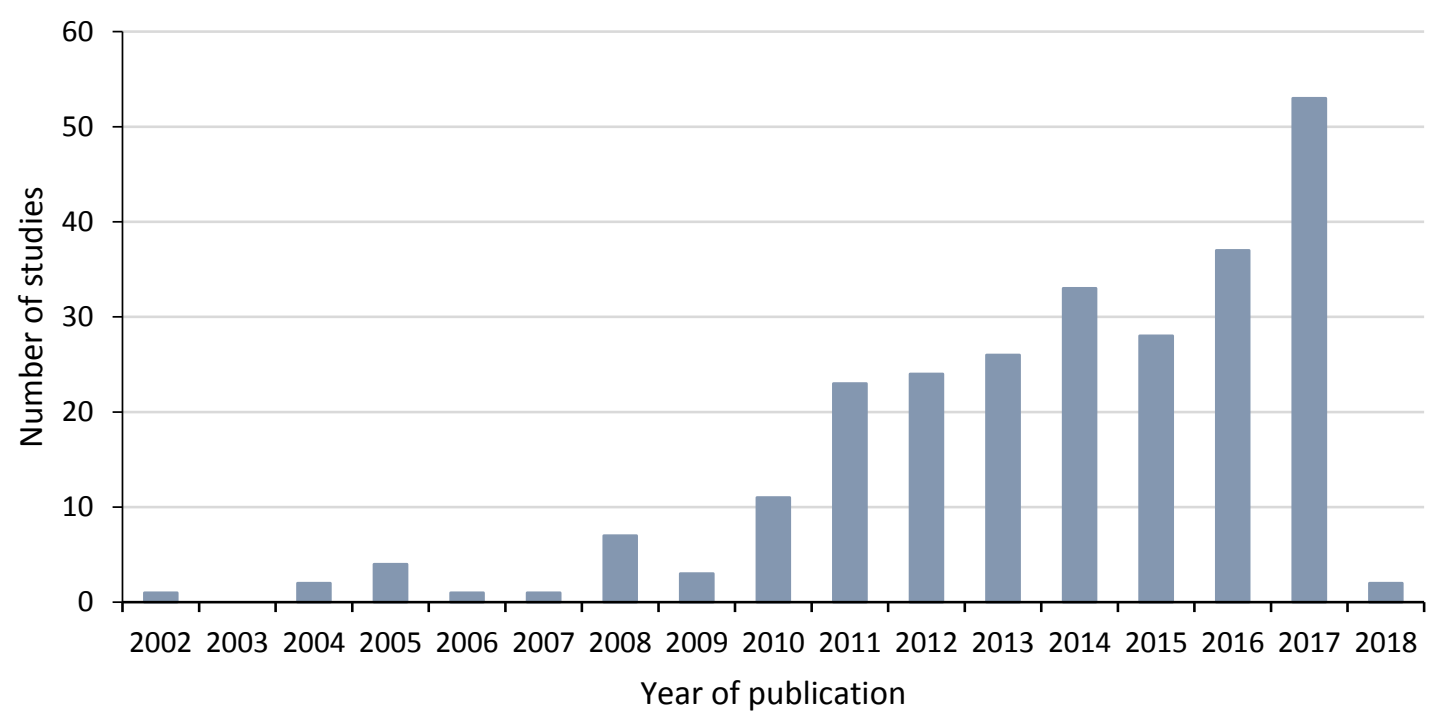

Figure 2. Number of reviewed papers on geotourism by year of publication (2018 extended to beginning of February). 
A geographical analysis of the study areas reveals a true global distribution (Figure 3), with a total of 53 countries represented. The largest share, or 136 studies, was conducted in Europe. Of these, the largest amount of research was conducted in Italy, with a total of 26 studies, while 20 studies were conducted in Poland, 15 in Serbia, and 10 each in United Kingdom and Slovakia. In Asia a total of 64 studies were conducted, with 14 studies conducted in both Iran and China and 13 studies conducted in Malaysia. A total of 19 studies were conducted in Africa, 6 of them in Egypt, 3 in Morocco and 2 in Cameroon. A total of 13 studies were conducted in Australasia, 10 in Australia and 3 in New Zealand. Only 12 studies were conducted in South America, 11 of them in Brazil, with the same number, 12, conducted in North America, including 7 in the United States.

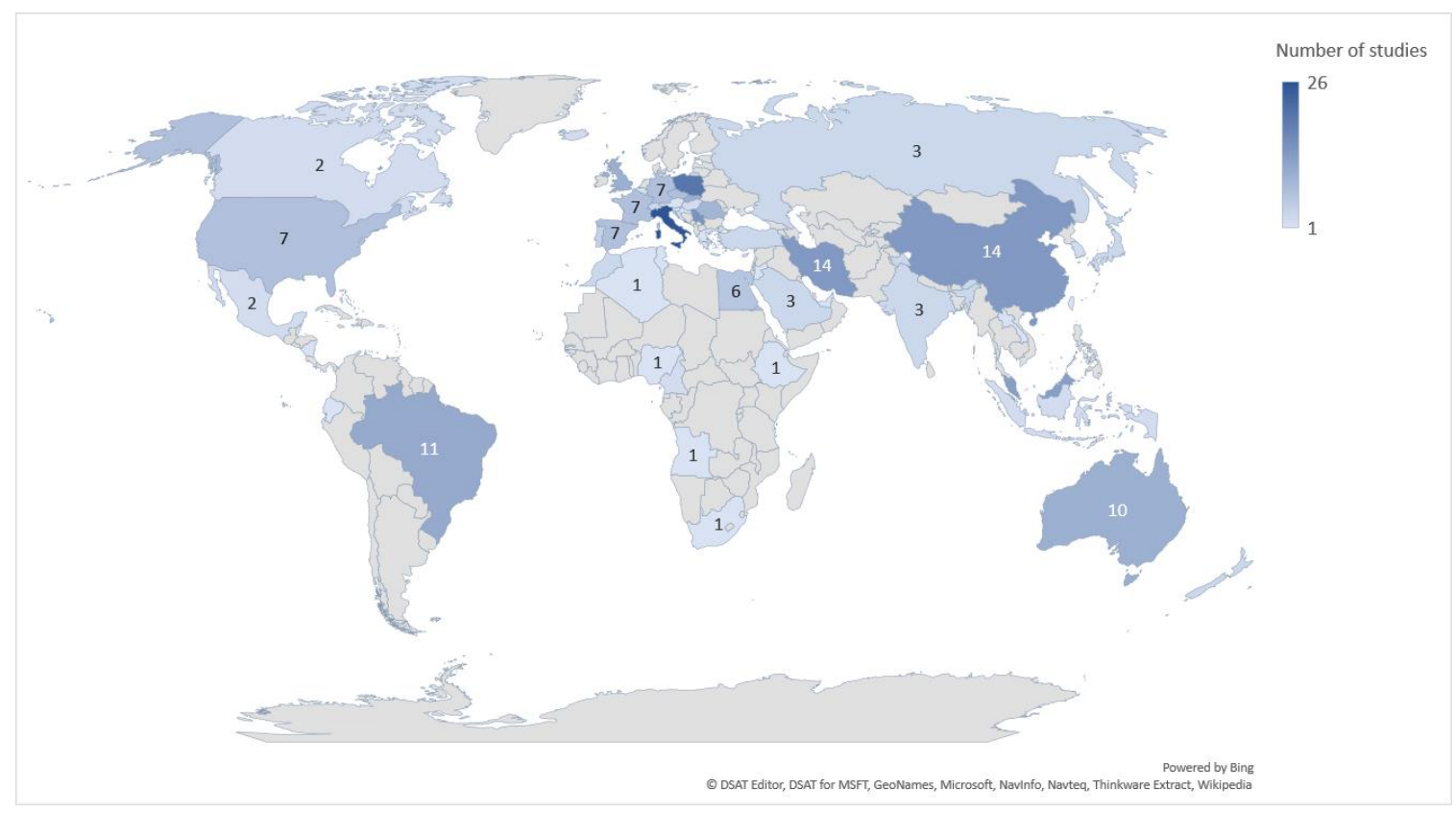

Figure 3. Geographical distribution of research studies on geotourism.

The papers selected for review are published in 86 different journals which focus on a wide range of disciplines (Table 1). A large proportion of the papers (41.4\%) are published in journals which focus on geoheritage and geotourism. Other dominant disciplines include geography (12.5\%), tourism $(10.9 \%)$, and geology $(8.2 \%)$. A total of $7.4 \%$ of the reviewed papers are published in journals which focus on the earth sciences, $3.9 \%$ on quaternary science, $3.1 \%$ on geosciences. Of the papers $6.3 \%$ were published in multidisciplinary journals, and $6.3 \%$ in journals with another disciplinary focus.

Table 1. Discipline and distribution of journals that published more than one paper on geotourism.

\begin{tabular}{cccc}
\hline Discipline & Journal Title & No. of Studies & $\%$ \\
\hline Geoheritage & Geoheritage & 74 & $28.9 \%$ \\
Geotourism & Geojournal of Tourism and Geosites & 23 & $9.0 \%$ \\
& Acta Geoturistica & 5 & $2.0 \%$ \\
Geography & Geotourism/Geoturystyka & 4 & $1.6 \%$ \\
& Quaestiones Geographicae & 10 & $3.9 \%$ \\
& Acta Geographica Slovenica & 4 & $1.6 \%$ \\
& Geographica Pannonica & 4 & $1.6 \%$ \\
& Journal of Maps & 3 & $1.2 \%$ \\
& Applied Geography & 2 & $0.8 \%$ \\
& Geografia Fisica e Dinamica Quaternaria & 2 & $0.8 \%$ \\
\hline
\end{tabular}


Table 1. Cont.

\begin{tabular}{|c|c|c|c|}
\hline Discipline & Journal Title & No. of Studies & $\%$ \\
\hline \multirow[t]{8}{*}{ Tourism } & e-Review of Tourism Research & 5 & $2.0 \%$ \\
\hline & Czech Journal of Tourism & 3 & $1.2 \%$ \\
\hline & International Journal of Tourism Research & 3 & $1.2 \%$ \\
\hline & Asia Pacific Journal of Tourism Research & 2 & $0.8 \%$ \\
\hline & Current Issues in Tourism & 2 & $0.8 \%$ \\
\hline & Tourism Geographies & 2 & $0.8 \%$ \\
\hline & Tourism Management Perspectives & 2 & $0.8 \%$ \\
\hline & Journal of Ecotourism & 1 & $0.4 \%$ \\
\hline Earth & Journal of African Earth Sciences & 9 & $3.5 \%$ \\
\hline \multirow[t]{2}{*}{ Sciences } & Acta Montanistica Slovaca & 5 & $2.0 \%$ \\
\hline & Environmental Earth Sciences & 3 & $1.2 \%$ \\
\hline \multirow[t]{3}{*}{ Geology } & Proceedings of the Geologists' Association & 7 & $2.7 \%$ \\
\hline & Bulletin of the Geological Society of Malaysia & 5 & $2.0 \%$ \\
\hline & Geologos & 2 & $0.8 \%$ \\
\hline Quaternary & Quaternary International & 6 & $2.3 \%$ \\
\hline \multirow[t]{2}{*}{ Science } & Alpine and Mediterranean Quaternary & 2 & $0.8 \%$ \\
\hline & Il Quaternario & 2 & $0.8 \%$ \\
\hline \multirow[t]{3}{*}{ Geosciences } & Open Geosciences & 3 & $1.2 \%$ \\
\hline & Anuario do Instituto de Geociencias & 2 & $0.8 \%$ \\
\hline & Episodes & 2 & $0.8 \%$ \\
\hline \multirow[t]{3}{*}{ Biology } & Advances in Environmental Biology & 2 & $0.8 \%$ \\
\hline & $\begin{array}{l}\text { Journals in which just one study was } \\
\text { published }\end{array}$ & 55 & $21.5 \%$ \\
\hline & Total: & 256 & $100.0 \%$ \\
\hline
\end{tabular}

The papers can be divided into several categories based on their central research topic. However, in many cases these categories overlap and are interconnected, given that the same paper often addresses several topics. The majority of the papers $(46.1 \%)$ focus on the geoheritage of the areas studied and their potential for geotourism development (Table 2). Other common research topics include geotourism and geoheritage management (12.5\%), tools for geoheritage promotion $(10.2 \%)$, and new methodologies, techniques, and geosite/geomorphosite assessment models $(9.8 \%)$. The results indicate that researchers show less interest in stakeholders of geotourism: tourist perceptions and motivation are a central research topic in 16 of the papers $(6.1 \%)$, while just two of the reviewed papers focus on local communities. Ten (3.9\%) of the papers examine geotourism in the context of sustainable development.

The vast majority of the papers (98.8\%) employ an empirical approach or use empirical data for testing proposed models and methodologies. The majority of the reviewed papers $(61.3 \%)$ are based upon a combination of qualitative and quantitative data, while a total of $22.1 \%$ of the papers exclusively use qualitative data, and $16.6 \%$ apply a quantitative approach (Table 3 ). Collection of primary data was carried out for $17.0 \%$ of the papers, $8.7 \%$ use secondary data, while the majority of the papers $(74 \%)$ employ both primary and secondary data for their research. The majority of the primary data $(68.8 \%)$ was collected via field work, including field surveys and sampling (Table 4). Other primary data collection methods include surveys of visitors, students, and local populations, interviews with managers and staff of geoparks and other geotourism destinations, tourists and other stakeholders, as well as questionnaires completed by experts and managers of the geoparks. Secondary data used in the papers was obtained via bibliographic research, analysis of cartographic materials, remote sensing, Geographic Information Systems (GIS) and satellite imagery, analysis of webpages and smartphone applications, and database and records searches. 
Table 2. Research topics covered in the reviewed papers.

\begin{tabular}{ccc}
\hline Research Topic & No. & \% \\
\hline Geoheritage/geotourism potential of the area & 118 & $46.1 \%$ \\
Geotourism/geoheritage management & 32 & $12.5 \%$ \\
Tools for geoheritage promotion & 26 & $10.2 \%$ \\
Techniques / models/methodologies & 25 & $9.8 \%$ \\
Tourists & 16 & $6.3 \%$ \\
Geotourism as a tool for sustainable development & 10 & $3.9 \%$ \\
Geotourism/geoconservation initiatives & 8 & $3.1 \%$ \\
Contextualizing literature on geotourism & 7 & $2.7 \%$ \\
Geoparks & 7 & $2.7 \%$ \\
New concepts in geotourism & 5 & $2.0 \%$ \\
Local communities & 2 & $0.8 \%$ \\
Total: & 256 & $100.0 \%$ \\
\hline
\end{tabular}

Table 3. Type of data collected in the reviewed papers.

\begin{tabular}{cccccc}
\hline Data & No. & \% & Data & No. & $\%$ \\
\hline Primary & 43 & $17.0 \%$ & Qualitative & 56 & $22.1 \%$ \\
Secondary & 22 & $8.7 \%$ & Quantitative & 42 & $16.6 \%$ \\
Both & 188 & $74.3 \%$ & Combination & 155 & $61.3 \%$ \\
Total: & 253 & $100.0 \%$ & Total: & 253 & $100.0 \%$ \\
\hline
\end{tabular}

Table 4. Data collection methods employed in the reviewed studies.

\begin{tabular}{ccc}
\hline Data Collection Methods & No. & $\%$ \\
\hline Field survey/sampling & 174 & $68.8 \%$ \\
Bibliographic research/literature review & 171 & $67.6 \%$ \\
Case study & 27 & $10.7 \%$ \\
Survey & 26 & $10.3 \%$ \\
Analysis of cartographic materials & 15 & $5.9 \%$ \\
Interviews & 12 & $4.7 \%$ \\
Remote sensing/GIS/satellite imagery & 8 & $3.2 \%$ \\
Questionnaire & 7 & $2.8 \%$ \\
Webpage/app analysis & 4 & $1.6 \%$ \\
Database and records search & 2 & $0.8 \%$ \\
Other & 11 & $4.3 \%$ \\
\hline
\end{tabular}

\subsection{Research Trends in Geotourism Which Have Evolved over the Past Two Decades}

The volume of research on the geoheritage of the study areas and their geotourism potential is growing at a rapid pace compared to papers on other topics (Figure 4). The number of papers focusing on the geoheritage and geotourism potential of the study areas grew from five papers in 2010 (45.5\% of all reviewed papers on geotourism in 2010) to 29 papers or $54.7 \%$ in 2017. Besides the inventorying, mapping, description, and analysis of the geosites and geomorphosites carried out based on the data from the field surveys, samples, and bibliographic research, many studies (49 studies in total) carried out geosite or geomorphosite assessment for the purpose of geoconservation and geotourism development. Eight of the papers employ SWOT (strengths and weaknesses, opportunities and threat) analysis of the geotourism potential of the study areas. The same number of papers focusing on the geoheritage of the study areas proposes a geotouristic itinerary in the areas studied based on collected data. 


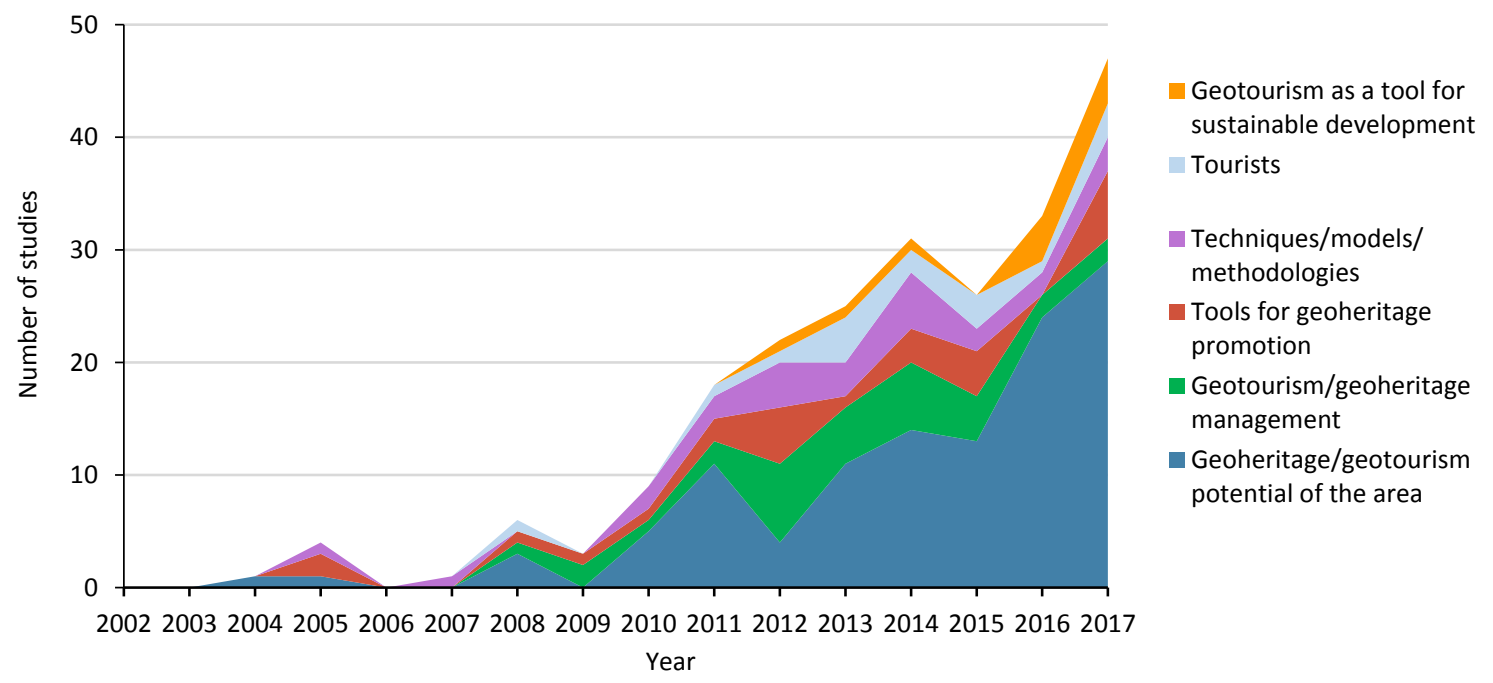

Figure 4. Temporal development of research topics related to geotourism.

The growing body of research investigating the geoheritage and geotourism potential of various areas creates a need for the development of geoheritage assessment models. Since 2010 two to five papers presenting geosite/geomorphosite assessment models and other methodologies have been published each year. The earliest reviewed paper [26] proposes a classification of geomorphosites based on their scenic, scientific, cultural/historical, and social/economic value. Reynard et al. [27] aimed to develop an easy-to-use assessment method and propose classification of geomorphosites based on scientific and additional values. Their methods were further developed and modified by various researchers [28-31]. Based on the previous research Vujičić et al. [32] developed a preliminary geosite assessment model (GAM), which was later modified by Tomić and Božić [33] to M-GAM by including tourists' opinions on the importance of indicators as part of the geosite assessment. Božić and Tomić [34] further investigated M-GAM by comparing the opinions of two different market segments: general geotourists, and pure geotourists. Mikhailenko et al. [35] proposed aesthetics-based classification of geological structures which has promising potential to facilitate identification of geological areas interesting to a wide range of visitors. The models which focus on studying tourist visitors to geotourism destinations include the Geotraveler Tendency Scale [36] and a geotourism typology model [37].

Papers which focus on tools for geoheritage promotion have a similar distribution across the period reviewed with an average proportion of $10.2 \%$. Most of these papers (9) present geotourist maps describing sites of potential interest to tourists. Bissig [38] presented an analysis of geotourist maps and concluded that more effort should be put into simplifying the communication of maps to make them more understandable to the average user. This, according to the author, could be achieved by researching visitors' needs. Another topic, addressed in six papers, is implementation of digital technologies for geoheritage promotion, which include mobile applications, videos, QR codes, games, laser scanning, 3D modelling, web-based dynamic maps, and web information monitoring and crowdsourcing. Two papers [39,40] investigate interpretative panels at geotourism destinations-with interesting results: while one paper [40] identifies a need to simplify the information on the panels in the study area and make it more understandable and more attractive to visitors, the second paper [39] characterizes the provision of only very simple and basic information in the study area as a missed opportunity to cultivate visitors' interest in the geosciences. Farsani et al. [41] conducted a study of the use of traditional handicrafts, and concluded that art can be successfully applied in geotourism. This was supported by Gordon [42] and Walliss and Kok [43] both of whom included art projects in their proposed interpretative strategies through direct experience. 
The proportion of papers focusing on geotourism and geoheritage management decreased from $9.1 \%$ in 2010 and $29.2 \%$ in 2012 to just $3.8 \%$ in 2017 . The highest proportion of papers which focus on management issues, 12 out of 32, investigate management issues in specific environments, such as geothermal areas and other volcanic areas, fossil sites, loess geosites, and caves which require increased attention due to their sensitivity or potential natural hazards. A total of 11 papers describe the challenges and present examples of successful geotourism development in geoparks. The main management challenges identified in geoparks and other geotourism destinations include potential overcrowding and subsequent impacts on the environment, including damage to geoheritage [44], the need for compromises between geotourism and geoconservation [45], the difficulty of communicating geological information in a way understandable to the wider public [46], insufficient funding for geoconservation in geoparks, lack of geoconservation strategies, and uncoordinated development of geotourism destinations [47-49], and visitor management in the presence of natural hazards [50,51]. Positive contributions made by geoparks and geotourism development include raising public awareness of the importance of geoconservation, providing the public with more information about the areas in question, improved distribution of visitors across the areas, longer length of stay, and a broader range of activities offered to visitors [52]. Gerner et al. [53] argued that effective geotourism marketing and management significantly contributed to successful development of the Lake Constance region. Newsome et al. [44] emphasized that geotourism can be a successful contributor to sustainable development only when properly managed, otherwise geotourism development can pose a threat to geoheritage. The authors suggested that successful management of popular geotourism destinations demands management of visitors and their numbers, provision of high quality geoheritage interpretation and appropriate infrastructure, as well as effective legislation. Kiernan [54] emphasized that appropriate management of geotourism destinations is especially lacking in developing countries, where priority is given to economic development over geoconservation. Other solutions proposed to improve the management of geotourism destinations include geospatial planning and geosite networking, which aim to include the objectives of various stakeholders [45] and Local Geodiversity Action Plans [55].

Geoparks are an important tool, combining geodiversity conservation with visitor education. In the papers which focus on geoparks and other geotourism and geoconservation initiatives (15 papers in total) the role of geoparks in the promotion of geotourism [56], representation of geodiversity [57] and geologic time [58] as well as their contribution to socio-economic rural development [59] are investigated, and examples of geopark development based on the type of geoheritage present in the area are presented [60-62]. Geotourism initiatives implemented outside the geoparks are also investigated [63,64]. The study conducted by Gladfelter and Mason [65] in Yosemite National Park concluded that although geotourism projects have the potential to influence visitor patterns and congestion problems in popular national parks and can make a positive contribution to the involvement of stakeholders, they may also increase environmental impacts.

A gradually increasing proportion of papers (7.5\% in 2017) examine geotourism as a tool for sustainable development and rural development. Dowling [14] presented several locations around the globe where geotourism has contributed to sustainable development, and states that geotourism contributes to local communities by providing direct, indirect, and induced employment. Ólafsdóttir and Dowling [66] state that geotourism can make a positive contribution to rural development in Iceland, and emphasize the importance of effective management to ensure sustainable geotourism development. The authors proposed managing geotourism destinations by applying planning zones: sanctuary, geoconservation, geotourism development, and outdoor recreation zones. Other papers [67-69] also view geotourism as a welcome alternative to unsustainable exploitation of resources and deterioration of natural landscapes, providing economic resources to local communities. However, the case of the Witsie Cave project, which is implementing community-based geotourism in South Africa [70], shows that geotourism development projects in rural areas may be facing serious challenges, such as lack of management and business skills, insufficient marketing, and low visitor 
numbers, resulting in a low level of income for local communities, which should be addressed by providing more financial support for the projects in question and involving more members of local communities. Moreover, a study conducted in Montana in the United States [71] revealed that local businesses participate in sustainable geotourism practices only to a relatively limited extent, which may also present a challenge when developing geotourism destinations and should be addressed in management strategies.

Although local communities play an important role in successful development of geotourism destinations, only two papers focus on attitudes among local people towards geotourism development in their local areas. The first of these studies [72] investigates the views of local people on the adaptation of an area degraded by mining activity for geotourism purposes, and establishes that most locals do not consider the area to be suitable for geotourism. The second study [73] investigates the attitudes of local people in the region of a geopark and identifies numerous benefits to local communities including improved job opportunities and increased income, as well as increased ethnic and cultural pride. Tourists are the group of geotourism stakeholders who receive the greatest attention, although the number of published papers which have tourists as their main focus is still relatively low, with up to four papers published each year focusing on tourists, their behavior and perceptions. Four papers investigate visitor perceptions of geoheritage in the study areas, five papers analyze the motivation of tourists to visit the study areas, two papers additionally investigate the connection between tourists' motivation and satisfaction [74], and between tourists' motivation and willingness to pay for guided tours [75]. Three papers [12,76,77] categorize visitors based on their attitudes and motivations, while two papers $[78,79]$ investigate visitors' opinions on and understanding of geo-interpretation materials, and propose improvements.

Certain areas and geoheritage types receive greater attention from researchers due to their specific characteristics (Figure 5). A total of 20 studies focus on volcanic geoheritage, on the basis that volcanism significantly shapes the landscape of the study areas, presents significant aesthetic value, the spectacular eruptions, hot springs and spas, black and green sand beaches, etc. which attract visitors [80,81], while at the same time presenting greater potential for natural hazards. Other major groups include mountain areas, urban geoheritage, quarries and mining areas, and geocultural geoheritage. Notably, a greater number of geosite/geomorphosite assessment models are tested in mountain areas, while one paper [82] presents a geomorphosite assessment model adapted specifically for gorges and another [83] for urban geoheritage. A high proportion of the research conducted in rural areas (3/5) focuses on geotourism as a tool for sustainable development. The majority of the studies conducted of caves (3/5) examine tourist motivations. A high proportion of the papers which focus on geotourism management examine volcanic and loess areas.

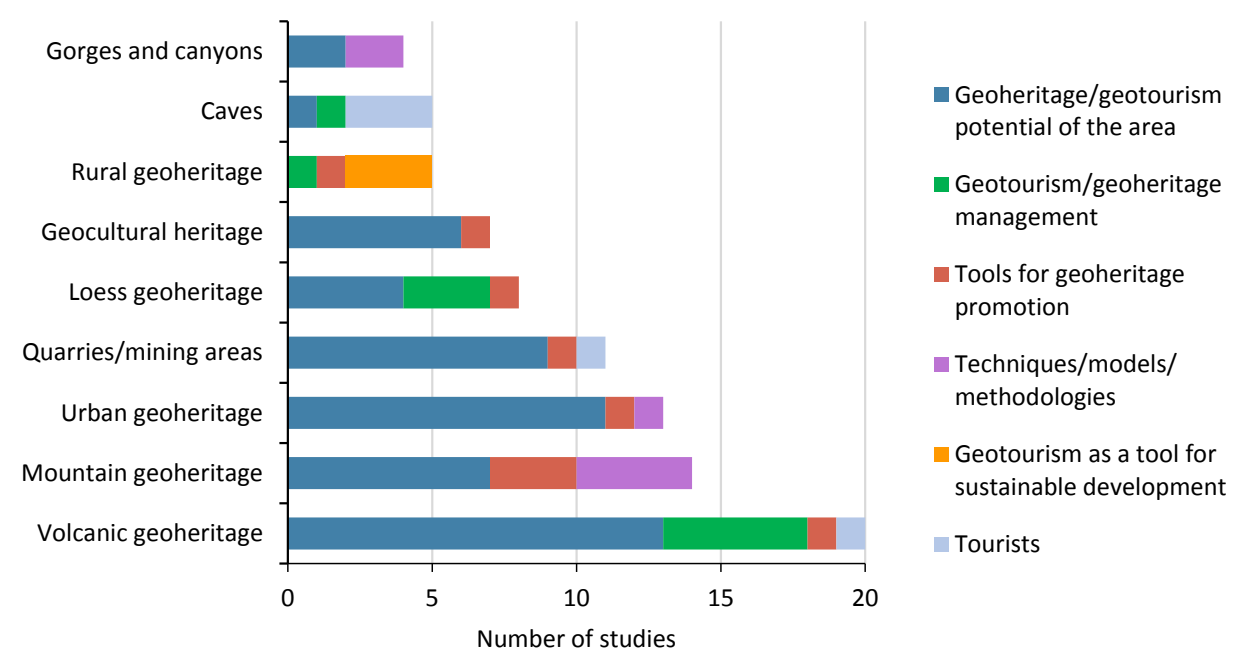

Figure 5. The major areas of geoheritage focus within geotourism research. 


\section{Discussion}

Since the first official definition of geotourism was put forward in 1995, geotourism as a field of research has been steadily growing, characterized by an exponential increase in publications over the past ten years. The results of the present literature review show that the most commonly researched topics include the description, inventorying, or assessment of the geoheritage and geotourism potential of the study areas, issues connected with geotourism and geoheritage management in existing or potential geotourism destinations, tools for geoheritage promotion, models for geosite/geomorphosite assessment and other methodological approaches, as well as the perceptions and motivations of tourists. According to Pica et al. [84] geoheritage studies and knowledge gathered concerning geosites and geomorphosites worldwide serve as a basis for geotourism development and successful geoconservation, emphasizing the need for literature reviews such as this one, which highlight the research development and major trends in the field. The results of the present review show that the four areas of research that Reynard [85] suggested may make significant contributions to the improvement of geotourism management, namely (1) assessment of geomorphosites; (2) mapping of geomorphosites for geotourism purposes; (3) development of tools for scientific mediation for the purpose of rendering the geosciences understandable to a large public; and (4) identification of tourists' needs, are all to a certain extent included in the studies published to date which focus on geotourism. However, certain areas require more attention than they have received to date. In order to successfully identify the most successful tools for scientific mediation and thereby improve the geo-education of visitors and locals at geotourism destinations, more knowledge needs to be gathered concerning the tourists who visit geotourism destinations, in particular their profile and their needs. This conclusion is supported by Fung and Jim [15], who point out the lack of research on visitors to geotourism destinations and emphasize the importance of such knowledge for successful visitor management and education at geotourism destinations. Information concerning visitors to geotourism destinations and their motivation is likely to facilitate the preparation of understandable and interesting information concerning the geology of each area and also contribute to raising awareness of the importance of geoheritage and thereby attract greater support for geoconservation. The results indicate gaps in knowledge in this area-a conclusion supported by various studies [38-40] which underline the difficulties of communicating scientific information to visitors.

The views and perceptions of another group of stakeholders, namely local communities, also require further research. As pointed out by Newsome and Dowling [3], providing benefits to local communities is one of the main principles of geotourism. These benefits include providing job opportunities and thereby raising the income of local people by creating or increasing the demand for accommodation and other tourism services, employing locals as guides or staff at geotourism destinations. As such, the success of geotourism development projects to a significant extent depends on local people having a positive attitude towards these projects. The results of the present study indicate a lack of knowledge on this topic, underpinning the importance of investing more effort into investigating how local communities view geotourism, and what factors affect these views. The results furthermore show that empirical knowledge regarding the actual contributions of geotourism to the wellbeing of local communities is currently in very short supply. For this reason, more studies are needed which aim to investigate how geotourism projects, including geoparks, affect local communities, the positive and negative impacts of such initiatives, what challenges associated with geotourism projects local communities experience, and how these challenges could be addressed.

Sustainability is one of the principal aims of geotourism, and it is something which should ideally be achieved via geo-education and geo-interpretation and by raising awareness among tourists and locals of the importance of preserving geoheritage, resulting in greater support for geoconservation, as emphasized by Newsome \& Dowling [3]. Many researchers [66,86-88] further emphasize the importance of geoconservation for geotourism, given that this form of tourism cannot function without sustainable management of geoheritage. However, it is important to keep in mind that popular geotourism destinations encounter the same challenges as other tourism destinations, including 
overcrowding and a wide range of negative impacts on geoheritage as well as on the vegetation and wildlife of these destinations. As such, sustainable development of geotourism destinations is only possible by systematically planning and managing geotourism destinations. Managing visitors and their behavior at popular geotourism destinations is nonetheless frequently a difficult and problematic task. This conclusion is supported by Newsome et al. [44], who demonstrate that not all geotourism destinations succeed in preserving the geoheritage of the areas in question. Empirical research conducted on the impacts of geotourism and knowledge concerning effective management solutions applied at geotourism destinations are therefore important contributions to sustainable geotourism management worldwide. Moreover, issues relating to geoheritage conservation may vary significantly depending among other things on the type of geoheritage, climate, local customs, and visitor behavior. As such, an extensive database of geotourism destinations worldwide would ensure the availability of the most appropriate management solutions for each geotourism destination.

Based on the empirical data collected at various geotourism destinations, further theoretical research is needed in areas where earlier research has proven to be problematic, namely communication of scientific information to the wider public in an understandable and attractive way, development of objective and widely applicable geosite/geomorphosite assessment models, and the integration of geoheritage conservation with recreation and interpretation services at geotourism destinations.

\section{Concluding Remarks}

In step with the growing popularity of geotourism as a new form of sustainable tourism, the body of research on geotourism has increased exponentially over the past two decades. Certain research areas, namely geoheritage and geotourism potential of various areas worldwide, receive a great deal of attention and make up a significant portion of the research conducted on geotourism, due to the fact that knowledge concerning geoheritage is fundamental for the development of geotourism. However, other topics require further research in order to provide the knowledge and understanding necessary for successful geotourism development and management. The main topics in need of further research may be classified into the following categories:

- Empirical knowledge concerning visitors to geotourism destinations, their profile, needs, preferences, and motivations;

- Empirical knowledge concerning the main challenges faced by the managers of geotourism destinations, and possible solutions;

- Empirical knowledge concerning positive and negative impacts of geotourism on geoheritage and other aspects of the natural environment, on local communities and other stakeholders at geotourism destinations.

Author Contributions: The research work has been designed and directed by the main author, R.O. The manuscript was prepared in close collaboration between the both authors. E.T. carried out most of the analysis. Both authors contributed to the interpretation and completion of the results.

Funding: This research received no external funding.

Conflicts of Interest: The authors declare no conflict of interest.

\section{References}

1. Hose, T.A. Towards a history of geotourism: Definitions, antecedents and the future. Geol. Soc. Lond. Spec. Publ. 2008, 300, 37-60. [CrossRef]

2. Hose, T.A. 3G's for modern geotourism. Geoheritage 2012, 4, 7-24. [CrossRef]

3. Newsome, D.; Dowling, R.K. Setting an agenda for geotourism. In Geotourism: The Tourism of Geology and Landscape; Newsome, D., Dowling, R., Eds.; Goodfellow Publishers Limited: Oxford, UK, 2010; pp. 1-12.

4. Hose, T. Selling the Story of Britain's Stone. Environ. Interpret. 1995, 10, 16-17.

5. Dowling, R.; Newsome, D. The scope and nature of geotourism. In Geotourism; Dowling, R., Newsome, D., Eds.; Routledge: Oxford, UK, 2006; pp. 31-53. 
6. Hose, T.A. European Geotourism-Geological Interpretation and Geoconservation Promotion for Tourists. In Geological Heritage: Its Conservation and Management; Barretino, D., Wimbledon, W.P., Gallego, E., Eds.; Instituto Tecnologico Geominero de Espana: Madrid, Spain, 2000; pp. 127-146.

7. Joyce, B. Geotourism, Geosites and Geoparks: Working together in Australia. Aust. Geol. 2007, 144, $26-29$.

8. Stokes, A.M.; Cook, S.D.; Drew, D. Geotourism: The New Trend in Travel; Travel Industry America and National Geographic Traveler: Washington, DC, USA, 2003.

9. Bosak, K.; Boley, B.; Zaret, K. Deconstructing the 'Crown of the Continent': Power, politics and the process of creating National Geographic's Geotourism Mapguides. Tour. Geogr. 2010, 12, 460-480. [CrossRef]

10. National Geographic. Geotourism MapGuides. Available online: https:/ /www.nationalgeographic.com/ maps/geotourism/geotourism-mapguides/ (accessed on 26 May 2018).

11. Boley, B.B.; Nickerson, N.P. Profiling geotravelers: An a priori segmentation identifying and defining sustainable travelers using the Geotraveler Tendency Scale (GTS). J. Sustain. Tour. 2013, 21, 314-330. [CrossRef]

12. Ollier, C. Problems of geotourism and geodiversity. Quaest. Geogr. 2012, 31, 57-61.

13. Dowling, R.K. Global geotourism-An emerging form of sustainable tourism. Czech J. Tour. 2013, 2, 59-79. [CrossRef]

14. Global Geoparks Network. Guidelines and Criteria for National Geoparks Seeking UNESCO's Assistance to Join the Global Geoparks Network (GGN). 2010. Available online: http:/ /www.unesco.org/new / fileadmin/ MULTIMEDIA/HQ/SC/pdf/sc_geoparcs_2010guidelines.pdf (accessed on 10 March 2018).

15. Henriques, M.H.; Brilha, J. UNESCO Global Geoparks: A strategy towards global understanding and sustainability. Episodes 2017, 40, 349-355. [CrossRef]

16. McKeever, P.J.; Zouros, N.C.; Patzak, M. The UNESCO global network of national geoparks. In Geotourism. The Tourism of Geology and Landscape; Newsome, D., Dowling, R.K., Eds.; Good Fellow Publishers Limited: Oxford, UK, 2010; pp. 221-230.

17. The European Geoparks Network. Introduction. Available online: http://www.europeangeoparks.org/ ?page_id=342 (accessed on 26 May 2018).

18. UNESCO. 13 Sites in Africa, Asia, Europe and North America Receive UNESCO Global Geopark Label. 2018. Available online: https:/ / en.unesco.org/news/13-sites-africa-asia-europe-and-north-america-receiveunesco-global-geopark-label (accessed on 21 May 2018).

19. Farsani, N.T.; Coelho, C.O.; Costa, C.M.; Amrikazemi, A. Geo-knowledge management and geoconservation via geoparks and geotourism. Geoheritage 2014, 6, 185-192. [CrossRef]

20. Ruban, D.A. Geotourism-A geographical review of the literature. Tour. Manag. Perspect. 2015, 15, 1-15. [CrossRef]

21. Booth, A.; Sutton, A.; Papaioannou, D. Systematic Approaches to a Successful Literature Review; Sage: Thousand Oaks, CA, USA, 2016.

22. Collins, J.A.; Fauser, B.C. Balancing the strengths of systematic and narrative reviews. Hum. Reprod. Update 2005, 11, 103-104. [CrossRef] [PubMed]

23. Petticrew, M. Systematic reviews from astronomy to zoology: Myths and misconceptions. BMJ Br. Med. J. 2001, 322, 98-101. [CrossRef]

24. Petticrew, M.; Roberts, H. Systematic Reviews in the Social Sciences: A Practical Guide; Blackwell: Oxford, UK, 2008.

25. Dowling, R.K. Geotourism's global growth. Geoheritage 2011, 3, 1-13. [CrossRef]

26. Pralong, J.-P.; Reynard, E. A proposal for the classification of geomorphological sites depending on their tourist value. Il Quaternario 2005, 18, 315-321.

27. Reynard, E.; Fontana, G.; Kozlik, L.; Scapozza, C. A method for assessing "scientific" and "additional values" of geomorphosites. Geogr. Helv. 2007, 62, 148-158. [CrossRef]

28. Kubalíková, L. Geomorphosite assessment for geotourism purposes. Czech J. Tour. 2013, 2, 80-104. [CrossRef]

29. Kubalíková, L.; Kirchner, K. Geosite and geomorphosite assessment as a tool for geoconservation and geotourism purposes: A case study from Vizovicka vrchovina highland (eastern part of the Czech Republic). Geoheritage 2016, 8, 5-14. [CrossRef]

30. Pereira, P.; Pereira, D. Methodological guidelines for geomorphosite assessment. Géomorphol. Relief Processus Environ. 2010, 16, 215-222. [CrossRef] 
31. Pica, A.; Fredi, P.; Del Monte, M. The Ernici Mountains Geoheritage (Central Apennines, Italy): Assessment of the Geosites for Geotourism Development. GeoJ. Tour. Geosites 2014, 7, 14.

32. Vujičić, M.D.; Vasiljević, D.A.; Marković, S.B.; Hose, T.A.; Lukić, T.; Hadžić, O.; Janićević, S. Preliminary geosite assessment model (GAM) and its application on Fruška Gora Mountain, potential geotourism destination of Serbia. Acta Geogr. Slov. 2011, 51, 361-376. [CrossRef]

33. Tomić, N.; Božić, S. A modified geosite assessment model (M-GAM) and its application on the Lazar Canyon area (Serbia). Int. J. Environ. Res. 2014, 8, 1041-1052.

34. Božić, S.; Tomić, N. Canyons and gorges as potential geotourism destinations in Serbia: Comparative analysis from two perspectives-general geotourists' and pure geotourists'. Open Geosci. 2015, 7, 531-546. [CrossRef]

35. Mikhailenko, A.V.; Nazarenko, O.V.; Ruban, D.A.; Zayats, P.P. Aesthetics-based classification of geological structures in outcrops for geotourism purposes: A tentative proposal. Geologos 2017, 23, 45-52. [CrossRef]

36. Boley, B.B.; Nickerson, N.P.; Bosak, K. Measuring geotourism: Developing and testing the geotraveler tendency scale (GTS). J. Travel Res. 2011, 50, 567-578. [CrossRef]

37. Hurtado, H.; Dowling, R.; Sanders, D. An exploratory study to develop a geotourism typology model. Int. J. Tour. Res. 2014, 16, 608-613. [CrossRef]

38. Bissig, G. Mapping geomorphosites: An analysis of geotourist maps. Geoturystika 2008, 3, 3-12.

39. Migoń, P.; Pijet-Migoń, E. Interpreting Geoheritage at New Zealand's Geothermal Tourist Sites-Systematic Explanation Versus Storytelling. Geoheritage 2017, 9, 83-95. [CrossRef]

40. Moreira, J.C. Interpretative panels about the geological heritage-A case study at the Iguassu Falls National Park (Brazil). Geoheritage 2012, 4, 127-137. [CrossRef]

41. Farsani, N.T.; Mortazavi, M.; Bahrami, A.; Kalantary, R.; Bizhaem, F.K. Traditional Crafts: A Tool for Geo-education in Geotourism. Geoheritage 2017, 9, 577-584. [CrossRef]

42. Gordon, J.E. Rediscovering a sense of wonder: Geoheritage, geotourism and cultural landscape experiences. Geoheritage 2012, 4, 65-77. [CrossRef]

43. Walliss, J.; Kok, K. New interpretative strategies for geotourism: An exploration of two Australian mining sites. J. Tour. Cult. Chang. 2014, 12, 33-49. [CrossRef]

44. Newsome, D.; Dowling, R.; Leung, Y.-F. The nature and management of geotourism: A case study of two established iconic geotourism destinations. Tour. Manag. Perspect. 2012, 2, 19-27. [CrossRef]

45. Harmon, B.; Viles, H. Beyond geomorphosites: Trade-offs, optimization, and networking in heritage landscapes. Environ. Syst. Decis. 2013, 33, 272-285. [CrossRef]

46. Garofano, M. Challenges in the popularization of the earth sciences. Geotourism as a new medium for the geology dissemination. Anuário do Instituto de Geociências 2012, 35, 34-41. [CrossRef]

47. Dong, H.; Song, Y.; Chen, T.; Zhao, J.; Yu, L. Geoconservation and geotourism in Luochuan loess national geopark, China. Quat. Int. 2014, 334, 40-51. [CrossRef]

48. Escorihuela, J.; Dowling, R.K. Analysis of the geotouristic activity in the geologic park of Aliaga, Spain: Progress, threats and challenges for the future. Geoheritage 2015, 7, 299-306. [CrossRef]

49. Wang, L.; Tian, M.; Wen, X.; Zhao, L.; Song, J.; Sun, M.; Wang, H.; Lan, Y.; Sun, M. Geoconservation and geotourism in Arxan-Chaihe Volcano Area, Inner Mongolia, China. Quat. Int. 2014, 349, 384-391. [CrossRef]

50. Master, S. Gaet'ale-a reactivated thermal spring and potential tourist hazard in the Asale salt flats, Danakil Depression, Ethiopia. J. Appl. Volcanol. 2016, 5, 1. [CrossRef]

51. Sheth, H.C.; Ray, J.S.; Bhutani, R.; Kumar, A.; Awasthi, N. The latest (2008-2009) eruption of Barren Island volcano, and some thoughts on its hazards, logistics and geotourism aspects. Curr. Sci. 2010, 98, 620-626.

52. Lima, E.A.; Machado, M.; Nunes, J.C. Geotourism development in the Azores archipelago (Portugal) as an environmental awareness tool. Czech J. Tour. 2013, 2, 126-142. [CrossRef]

53. Gerner, D.; Rybár, P.; Engel, J.; Domaracká, L. Geotourizm marketing in Lake Constance'region. Acta Montan. Slov. 2009, 14, 197.

54. Kiernan, K. The nature conservation, geotourism and poverty reduction nexus in developing countries: A case study from the Lao PDR. Geoheritage 2013, 5, 207-225. [CrossRef]

55. Burek, C. The role of LGAPs (Local Geodiversity Action Plans) and Welsh RIGS as local drivers for geoconservation within geotourism in Wales. Geoheritage 2012, 4, 45-63. [CrossRef]

56. Alexandrowicz, Z. Geopark-nature protection category aiding the promotion of geotourism (Polish perspectives). Geoturystyka 2006, 2, 3-12. 
57. Ruban, D.A. Geodiversity as a precious national resource: A note on the role of geoparks. Resour. Policy 2017, 53, 103-108. [CrossRef]

58. Ruban, D.A. Representation of geologic time in the global geopark network: A web-page study. Tour. Manag. Perspect. 2016, 20, 204-208. [CrossRef]

59. Farsani, N.T.; Coelho, C.; Costa, C. Geotourism and geoparks as novel strategies for socio-economic development in rural areas. Int. J. Tour. Res. 2011, 13, 68-81. [CrossRef]

60. Miller, R.F.; Buhay, D.N. Turning a Forgotten Geological Heritage into a Geological Park: Developing Stonehammer Geopark. Geoheritage 2014, 6, 29-39. [CrossRef]

61. Ramsay, T. Fforest Fawr Geopark-A UNESCO Global Geopark distinguished by its geological, industrial and cultural heritage. Proc. Geol. Assoc. 2017, 128, 500-509. [CrossRef]

62. Wang, L.; Tian, M. A discussion on the development model of earthquake relic geopark-A case study of the Qingchuan Earthquake Relic Geopark in Sichuan Province, China. J. Cult. Herit. 2014, 15, 459-469. [CrossRef]

63. Miccadei, E.; Piacentini, T.; Esposito, G. Geomorphosites and geotourism in the parks of the Abruzzo region (Central Italy). Geoheritage 2011, 3, 233-251. [CrossRef]

64. Piacentini, T.; Castaldini, D.; Coratza, P.; Farabollini, P.; Miccadei, E. Geotourism: Some examples in northern-central Italy. GeoJ. Tour. Geosites 2011, 8, 240-262.

65. Gladfelter, S.; Mason, R.J. Beyond boundaries: An assessment of the Yosemite National Park geotourism initiative. Tour. Plan. Dev. 2012, 9, 355-368. [CrossRef]

66. Ólafsdóttir, R.; Dowling, R. Geotourism and geoparks-A tool for geoconservation and rural development in vulnerable environments: A case study from Iceland. Geoheritage 2014, 6, 71-87. [CrossRef]

67. Hakim, L.; Soemarno, M. Biodiversity conservation, community development and geotourism development in Bromo-Tengger-Semeru-Arjuno Biosphere Reserve, East Java. GeoJ. Tour. Geosites 2017, 20, 220-230.

68. Marlina, E. Geotourism as a strategy of geosite empowerment towards the tourism sustainability in Gunungkidul regency, Indonesia. Int. J. Smart Home 2016, 10, 131-148.

69. Velazquez, V.F.; Colonna, J.; Pletsch, M.; da Silva, G.A.R.; Junior, O.L.; Ferreira, J.M.R.; Sobrinho, J.M.A.; Sallun, A.E.M.; Sallun Filho, W. The current situation of protection and conservation of the Colônia impact crater, São Paulo, Brazil. GeoJ. Tour. Geosites 2016, 4, 7-20.

70. Mukwada, G.; Sekhele, N. The Potential of Community-based Geotourism in Rural Development in South Africa: The Case of Witsie Cave Project. J. Asian Afr. Stud. 2017, 52, 471-483. [CrossRef]

71. Jorgenson, J.; Nickerson, N. Geotourism and sustainability as a business mindset. J. Hosp. Mark. Manag. 2016, 25, 270-290. [CrossRef]

72. Čech, V.; Krokusová, J. Utilisation of environmentally degraded area by mining activity: A case study of Slovinky tailing impoundment in Slovakia. Acta Montan. Slov. 2017, 22, 180-192.

73. Shahhoseini, H.; Modabberi, S.; Shahabi, M. Study of factors influencing the attitude of local people toward geotourism development in Qeshm National Geopark, Iran. Geoheritage 2017, 9, 35-48. [CrossRef]

74. Shavanddasht, M.; Karubi, M.; Sadry, B. An examination of the relationship between cave tourists' motivations and satisfaction: The case of Alisadr cave, Iran. GeoJ. Tour. Geosites 2017, 20, 165-176.

75. Cheung, L.T. The effect of geopark visitors' travel motivations on their willingness to pay for accredited geo-guided tours. Geoheritage 2016, 8, 201-209. [CrossRef]

76. Fung, C.K.; Jim, C. Segmentation by motivation of Hong Kong Global Geopark visitors in relation to sustainable nature-based tourism. Int. J. Sustain. Dev. World Ecol. 2015, 22, 76-88.

77. Kim, S.S.; Kim, M.; Park, J.; Guo, Y. Cave tourism: Tourists' characteristics, motivations to visit, and the segmentation of their behavior. Asia Pac. J. Tour. Res. 2008, 13, 299-318. [CrossRef]

78. Crawford, K.R.; Black, R. Visitor understanding of the geodiversity and the geoconservation value of the Giant's Causeway world heritage site, Northern Ireland. Geoheritage 2012, 4, 115-126. [CrossRef]

79. Mansur, K.L.; da Silva, A.S. Society's response: Assessment of the performance of the "Caminhos Geológicos" ("geological paths") project, State of Rio de Janeiro, Brazil. Geoheritage 2011, 3, 27-39. [CrossRef]

80. Sigurdsson, H.; Lopes-Gautier, R. Volcanoes and tourism. In Encyclopedia of Volcanoes; Sigurdsson, H., Ed.; Academic Press: San Diego, CA, USA, 2000; pp. 1283-1299.

81. Dóniz-Páez, J.; Becerra-Ramírez, R.; González-Cárdenas, E.; Guillén-Martín, C.; Escobar-Lahoz, E. Geomorphosites and geotourism in volcanic landscape: The example of La Corona del Lajial cinder cone (El Hierro, Canary Islands, Spain). GeoJ. Tour. Geosites 2011, 2, 185-197. 
82. Cocean, G.; Cocean, P. An assessment of gorges for purposes of identifying geomorphosites of geotourism value in the Apuseni Mountains (Romania). Geoheritage 2017, 9, 71-81. [CrossRef]

83. Pica, A.; Luberti, G.M.; Vergari, F.; Fredi, P.; Del Monte, M. Contribution for an urban geomorphoheritage assessment method: Proposal from three geomorphosites in Rome (Italy). Quaest. Geogr. 2017, 36, 21-36. [CrossRef]

84. Pica, A.; Reynard, E.; Grangier, L.; Kaiser, C.; Ghiraldi, L.; Perotti, L.; Del Monte, M. GeoGuides, urban geotourism offer powered by mobile application technology. Geoheritage 2017, 10, 311-326. [CrossRef]

85. Reynard, E. Scientific research and tourist promotion of geomorphological heritage. Geogr. Fis. Dinam. Quat. 2008, 31, 225-230.

86. Hose, T.A. The English origins of geotourism (as a vehicle for geoconservation) and their relevance to current studies. Acta Geogr. Slov. 2011, 51, 343-359. [CrossRef]

87. Hose, T.A.; Vasiljević, D.A. Defining the nature and purpose of modern geotourism with particular reference to the United Kingdom and South-East Europe. Geoheritage 2012, 4, 25-43. [CrossRef]

88. Migoń, P.; Pijet-Migon, E. Viewpoint geosites-Values, conservation and management issues. Proc. Geol. Assoc. 2017, 128, 511-522. [CrossRef]

(C) 2018 by the authors. Licensee MDPI, Basel, Switzerland. This article is an open access article distributed under the terms and conditions of the Creative Commons Attribution (CC BY) license (http://creativecommons.org/licenses/by/4.0/). 